\title{
The Ambassadorial LPs of Dizzy Gillespie: World Statesman and Dizzy in Greece
}

\section{DARREN MUELLER}

\begin{abstract}
In 1956, trumpeter Dizzy Gillespie became the first jazz musician to participate in the State Department's Cultural Presentations program, a highly public aspect of U.S. Government's Cold War propaganda efforts abroad. Seeking to capitalize on this historic moment, Gillespie's record company issued two LPs featuring his ambassadorial ensemble: World Statesman (1956) and Dizzy in Greece (1957). To date, scholarship about the tours highlights how Gillespie skillfully navigated the shifting political landscape both on and off the bandstand. The role that commercial record making played in the renegotiation of African Americans' social position during this era, however, remains undertheorized. This article reveals how, despite the albums' claims of representation from abroad, the LPs contain only a small portion of Gillespie's tour repertoire. I argue that these LPs were never meant to document the tours with veracity; rather, they were products of a political and technological moment when Gillespie's record label could leverage musical diplomacy to circulate an elevated vision for jazz within the country's cultural hierarchy.
\end{abstract}

In 1956, Dizzy Gillespie became the first jazz musician to participate in the State Department's Cultural Presentations program, a multifarious initiative to positively influence public attitudes towards the United States around the world while simultaneously fighting communist propaganda. ${ }^{1}$ During two tours that year, Gillespie's large jazz ensemble performed more than one hundred concerts in eleven countries in Eastern Europe, the Middle East, and South America. ${ }^{2}$ A few months after the band returned from its second tour (to South America), Gillespie's recording label, Norgran, released Dizzy Gillespie: World Statesman, the first of two LPs purporting to document the band's ambassadorial trips. Along with a title that intimates political leadership, the liner notes, written by acclaimed jazz researcher Marshall Stearns, recount anecdotes from local newspapers and present the music as the "first half" of a tour concert. Dizzy in Greece, the second LP, took a similar approach. The disc placed Gillespie in a location of specific political relevance and portrayed the music as a concert for the State Department. ${ }^{3}$

${ }^{1}$ A 1956 document about the program prepared for a congressional hearing states: "The primary objectives of the cultural (artistic and athletic) presentations program are (1) to improve the understanding in foreign countries regarding the cultural achievements of the United States and (2) to serve as a method for refuting Communist propaganda that the United States is a nation of cultural barbarians." The Supplemental Appropriation Bill, 1957: Hearings before the Committee on Appropriations, United States Senate, Eighty-Fourth Congress, Second Session, on H.R. 12138, an Act Making Supplemental Appropriations for the Fiscal Year Ending June 30, 1957, and for Other Purposes (Washington, D.C.: U.S. Government Printing Office, 1956), 443.

${ }^{2}$ From March to May 1956, Gillespie's ensemble traveled to Iran, Pakistan, Lebanon, Syria, Turkey, Greece and Yugoslavia. The band then toured South America from July to August of the same year, performing in Ecuador, Argentina, Uruguay, and Brazil.

${ }^{3}$ Marshall Stearns, liner notes to World Statesman, Norgran Records MG N-1084, 1956, LP (12in); Marshall Stearns, liner notes to Dizzy in Greece, Verve MV-2630, 1957, LP (12in). 
The LPs were well received by the jazz press. World Statesman appeared as a national bestseller in Down Beat four times between March and June 1957. ${ }^{4}$ Despite criticizing the occasional lack of precision, reviewer Nat Hentoff characterized the band's music as "a collective storm" and Gillespie's playing in particular as "masterly." Dizzy in Greece, issued at the end of 1957, received four out of five stars from Down Beat's Don Gold. Gillespie's playing on the record, according to Gold, is "the epitome of creative jazz" that "glows with warmth and excitement." Gold goes on to extol the "incomparable drive" of the band and the "fascinating" arrangements as "the best efforts of some of jazz' best writers." Although he recommends this album as one "worth owning and hearing often," he does remark that there is "no evidence that an audience is present for this concert performance, in Greece or anywhere else." He further observes that the title "seems to be justification for use of the cover photo, of Gillespie in Greek garb." ${ }^{\prime 6}$

Gold was right to question the name, discographical details, and motivations of this record. The material on both records resulted from two recording sessions in New York City in June 1956 and April 1957. Moreover, several surviving programs from the Middle East tour reveal that despite their claim to represent performances abroad, the LPs contain only a small cross section of the repertory Gillespie and his band played during the State Department tours. The records also omit Gillespie's humorous interactions with band members and the audience that were a regular part of the band's onstage performance, as concurrent live recordings evince.

Using the discrepancies between the commercial recordings and tour performances as a starting point, this study interrogates how the business of selling jazz records intersected with nationwide debates about cultural diplomacy, international affairs, and racial politics in the United States at mid-century. Unlike the tour concerts, which served a specific political purpose for international audiences, the LPs were specifically designed so that domestic consumers might imagine jazz standing for the political ideals of the United States. I argue that these records were never meant to document the tours with veracity. Rather, the LPs were the product of a political and technological moment when Gillespie's record label could leverage musical diplomacy to sell records and thereby circulate an elevated vision for jazz within the country's cultural hierarchy.

\section{Dizzy Gillespie as World Statesman}

During the immediate post-WWII period, from 1945 to 1960, more than forty countries containing roughly a quarter of the world's population (approximately 800 million people) gained independence. In the fight for political dominance in

${ }^{4}$ A review of World Statesman appeared in the December 1956 issue of Down Beat, although the record did not appear on the bestseller list until the 6 March 1957 issue. The LP charted in four out of the next five lists: \#13 (March 6), \#12 (April 4), \#13 (May 2), N/A (May 30), \#16 (June 27). See "Best Sellers" in Down Beat: 27 June 1957, 24; 30 May 1957, 22; 2 May 1957, 24; 4 April 1957, 21; and 6 March 1957, 32.

${ }^{5}$ Nat Hentoff, "World Statesman (review)," Down Beat, 26 December 1956, 30.

${ }^{6}$ Don Gold, “Dizzy Gillespie: Dizzy in Greece (review),” Down Beat, 28 November 1957, $28-29$. Dizzy in Greece never appeared on the bestselling jazz charts in 1957 or 1958. 
these decolonized states, race relations and the Jim Crow institutional discrimination laws in the United States became a major point of emphasis for Soviet propaganda efforts. ${ }^{7}$ As early as 1946, Soviet propagandists distributed reports about lynchings and poor labor conditions in the southern United States. ${ }^{8}$ The State Department responded in several ways, one of which was to increase the visibility of African Americans abroad by sending distinguished authors, athletes, journalists, classical musicians, and other intellectuals on missions of cultural exchange. In the early 1950s, author J. Saunders Redding, journalist Carl T. Rowan, high jumper Gilbert Cruter, classical vocalist William Warfield, and the Harlem Globetrotters all toured on behalf of the U.S. government. ${ }^{9}$ The State Department also began placing African Americans in their embassies across the world and allowed prominent figures such as attorney Edith Sampson to speak at public events. ${ }^{10}$ Representative Adam Clayton Powell, Jr., one of the few black members of Congress, succinctly summarized this strategy when he told President Eisenhower in 1955 that "one dark face from the U.S. is as much value as millions of dollars in economic aid." 11

That same year, Representative Powell helped persuade Eisenhower that jazz could be a useful addition in fighting Soviet propaganda abroad. ${ }^{12}$ The American National Theater Academy (ANTA) oversaw the evaluation of participants for the Cultural Presentations program. With little knowledge about jazz, ANTA's music advisory panel sought the expertise of Marshall Stearns, who recommended Gillespie along with several other musicians. ${ }^{13}$ Gillespie's dynamic ability and charismatic personality made him an ideal choice, although some policy makers in Washington still had concerns about sending jazz overseas. In a letter dated 30 January 1956, ANTA's general manager Robert C. Schnitzer asked Stearns to accompany Gillespie's band and advised him that "every precaution must be taken to assure that America's popular music is presented in such a way as to achieve

\footnotetext{
${ }^{7}$ Penny Von Eschen, Race against Empire: Black Americans and Anticolonialism, 1937-1957 (Ithaca, NY: Cornell University Press, 1997), 109, 116, 137; Ingrid Monson, Freedom Sounds: Civil Rights Call out to Jazz and Africa (New York: Oxford University Press, 2007), 111.

${ }^{8}$ Mary L. Dudziak, Cold War Civil Rights: Race and the Image of American Democracy (Princeton, NJ: Princeton University Press, 2000), 37-39.

${ }^{9}$ Von Eschen, Race against Empire, 148, 197. For more details about the relevant congressional bills, see Monson, Freedom Sounds, 111-12. An excellent resource about music in the Cultural Presentations program is Danielle Fosler-Lussier, Music in America's Cold War Diplomacy (Oakland: University of California Press, 2015).

${ }^{10}$ Dudziak, Cold War Civil Rights, 59-61.

${ }^{11}$ Von Eschen, Race against Empire, 148.

${ }^{12}$ In August of 1954, Congress authorized the President's emergency fund for Participation in International Affairs. This funding source was made permanent in 1956 through the International Cultural Exchange and Trade Fair Participation Act (PL-806). See Lisa E. Davenport, Jazz Diplomacy: Promoting America in the Cold War Era (Jackson: University Press of Mississippi, 2009), 39. For more on the decisions to feature Western art music on these tours, see Fosler-Lussier, Music in America's Cold War Diplomacy, 9-13, 23-27. An overview of jazz as a diplomatic tool can be found in Penny Von Eschen, Satchmo Blows up the World: Jazz Ambassadors Play the Cold War (Cambridge, MA: Harvard University Press, 2004).

${ }^{13}$ After attending several meetings of the advisory panel at the end of 1955, Stearns became a permanent member in January 1956. H. Alwyn Inness, Vice Chairman, to Stearns, 24 January 1956, box 11 folder 28, The Marshall Winslow Stearns Collection (MC 030), Rutgers University Libraries, Institute of Jazz Studies (hereafter MSC). Stearns initially named Louis Armstrong, Duke Ellington, Count Basie, Dizzy Gillespie, and Stan Kenton as top choices. See Monson, Freedom Sounds, 112-14.
} 
the best results for our national prestige." He continued, "We would also depend upon you to keep an eye on Dizzy's programs in order to see that he maintains the standards that have been set for them." ${ }^{14}$ From Gillespie's perspective, the trip presented an enormous musical opportunity because it allowed him to front a big band once again, something he had attempted several times previously with little financial success. ${ }^{15}$

While on tour, Gillespie both praised the progress in U.S. race relations and spoke openly about Emmett Till, whose gruesome murder in 1955 made tangible the violent realities of African American life. ${ }^{16}$ According to Jet magazine, local populations closely questioned Gillespie about Till's murder and about Autherine Lucy, the first black student to attend (and be unjustly expelled from) the University of Alabama. ${ }^{17}$ In his autobiography, Gillespie also pridefully acknowledges the racially mixed and gender-inclusive demographics of his band, or what he called an "American assortment' of blacks, whites, males, females, Jews, and Gentiles." 18 Gillespie viewed jazz as a tool for goodwill that could "bring people together." ${ }^{19}$ In doing so, he also articulated a vision of the United States that was hybrid, mixed, and diverse, a position that many African American community leaders and public figures expressed at the time. ${ }^{20}$ On stage, this way of thinking translated into skillful performances that entertained and educated through a combination of humor, wit, and musical displays of virtuosity.

\section{The LPs in Context}

Reports of Gillespie's activities abroad appeared in a wide array of print media. Jazz periodicals such as Down Beat and Metronome followed the tours closely, beginning with the official announcement from the State Department in November 1955. Coverage also appeared in the major newspapers of New York, Washington, Baltimore, Philadelphia, Salt Lake City, and San Francisco, in addition to media that

${ }^{14}$ Robert C. Schnitzer, General Manager of ANTA, to Stearns, 30 January 1956, b11 f28, MSC.

${ }^{15}$ For an overview of Gillespie's activities with a big band, see Donald L. Maggin, Dizzy: The Life and Times of John Birks Gillespie (New York: Harper Entertainment, 2005), 197-214, 233-39; Alyn Shipton, Groovin' High: The Life of Dizzy Gillespie (New York: Oxford University Press, 1999), 179-210, 275-92.

${ }^{16}$ For a view of Gillespie's actions in relation to other black entertainers navigating similar political terrain, see Richard Iton, In Search of the Black Fantastic: Politics and Popular Culture in the Post-Civil Rights Era (New York: Oxford University Press, 2008). A reading of Gillespie's activities as part of the "psychological" warfare of the State Department can be found in David Carletta, "Those White Guys Are Working For Me: Dizzy Gillespie, Jazz, And The Cultural Politics Of The Cold War During the Eisenhower Administration," International Social Science Review 82, nos. 3-4 (2007): 115-34.

17 “Dizzy Gillespie, Nat Cole Entertain President," Jet, 7 June 1956.

${ }^{18}$ Dizzy Gillespie and Al Fraser, To Be, or Not ... To Bop (Garden City, NY: Doubleday, 1979), 414. The band included trombonist Melba Liston and, for the Middle East tour, vocalist Dottie Saulters.

${ }^{19}$ Gillespie and Fraser, To Be or Not, 414. While entertaining President Eisenhower at the 1956 White House Press Correspondents' dinner, Gillespie similarly told Jet magazine, "My purpose in making the tour was to create goodwill for the U.S., and believe me, we sure need it over there." See "Dizzy Gillespie, Nat Cole Entertain President."

${ }^{20}$ For an overview of the various, sometimes conflicting, ways in which African American leaders promoted a pluralistic and diverse view of the country, see Waldo E. Martin, No Coward Soldiers: Black Cultural Politics and Postwar America (Cambridge, MA: Harvard University Press, 2005), 31-43. 
catered specifically to African Americans. These periodicals included newspapers such as the Pittsburgh Courier, New York Amsterdam News, and Arkansas State Press, as well as magazines like Hue and Jet. Between April 1956 and July 1957, Esquire, Saturday Review, Variety, Newsweek, and Time-magazines that generally targeted an educated, middle-class audience-similarly published articles about this new, ambassadorial role for jazz. ${ }^{21}$

This exposure led to numerous performance opportunities for Gillespie's ensemble. Between their return from the Middle East and the ensemble's second tour in South America in the summer of 1956, the band performed in New York City at Birdland and the Apollo Theater, at the White House for President Eisenhower, as well as at a civil rights rally in Detroit. Gillespie also made an appearance on Edward R. Murrow's Person to Person TV show. ${ }^{22}$ From the Apollo to the White House and from television to print media, Gillespie's role as a cultural ambassador circulated through all layers of U.S. society, and his music was in high demand with audiences on both sides of the color line.

Within this mediascape, the owner of Gillespie's label, Norman Granz, issued two LPs featuring the State Department band, no doubt seeking to take advantage of this publicity. ${ }^{23}$ The first, World Statesman, featured ten tracks of the band's material. Recorded in a single session on 6 June 1956 in a New York studio, World Statesman began to circulate later that year on Norgran, Gillespie's label at the time. ${ }^{24}$ Granz issued the second ambassadorial LP, Dizzy in Greece, at the end of 1957 on his newly formed Verve label. Of the disc's ten tracks, seven were from the same June 1956 recording session that produced World Statesman; Gillespie's band recorded the other three in April 1957 (see Table 1). ${ }^{25}$

Gillespie infused his big band with the musical qualities of bebop, emphasizing individual and often virtuosic improvisation. The band's compositions and arrangements feature complex melodies, intricate harmonies, and swift tempos mixed with typical gestures in the big band style: call-and-response figures between the brass and reed sections, melodies harmonized in four or five parts, full-band interludes between solos, and a chorus of through-composed material arranged for the entire ensemble in what is usually referred to as an "arranger's" or "shout" chorus. Tracks last between two-and-half to six minutes, with little variation in form. The typical arrangement includes an eight- to twelve-measure introduction,

\footnotetext{
${ }^{21}$ See the 1956 and 1957 folders, Dizzy Gillespie, Newspaper Clippings, Rutgers University Libraries, Institute of Jazz Studies (hereafter cited as Gillespie Clippings, IJS).

${ }^{22}$ Maggin, Dizzy, 282; Nat Hentoff, "Dizzy Gillespie Orchestra: Birdland, New York,” Down Beat, 11 July 1956, 18; "Dizzy Gillespie, Nat Cole Entertain President”; "Dizzy Winds up 'Person-Person' Show Friday," The Washington Afro-American, 26 June 1956, 17.

${ }^{23}$ Gillespie signed with Granz in 1953 , resulting in a diverse stream of recordings featuring the trumpeter with strings, big bands, a large Afro-Cuban ensemble, and various small groups.

${ }^{24}$ Many discographies incorrectly list three studio dates-18 and 19 May and 6 June-that produced the ambassadorial LPs. Biographer Alyn Shipton, for example, cites these dates based on studio sheets from Verve's archives. Shipton, Groovin' High, 285-86. Despite the paper trail, the 18 and 19 May studio dates are unlikely since the official State Department records place the band in Greece May 12-21. Monson, Freedom Sounds, 115. In his World Statesman review, Nat Hentoff describes the LP being made in one "nonstop, 90-minute" session. Hentoff, "World Statesman (review)."

${ }^{25}$ Verve issued the other tracks recorded during the April 1957 session on Dizzy Gillespie, Birks' Works, Verve MG V-8222, 1957, LP (12in).
} 
Table 1. Track listing and recording dates for World Statesman and Dizzy in Greece.

\begin{tabular}{lll}
\hline Record & & Recording Date \\
\hline World Statesman & Dizzy's Business & 6 June 1956 \\
Side 1 & Jessica's Day & \\
& Tour De Force & \\
& I Can't Get Started & \\
& Doodlin' & \\
& Night in Tunisia & \\
Side 2 & Stella by Starlight & \\
& The Champ & \\
& My Reverie & \\
& Dizzy's Blues & \\
Dizzy in Greece & & \\
Side 1 & Hey Pete! & \\
& Yesterdays & \\
& Tin Tin Deo & \\
& Groovin' For Nat & \\
Side 2 & Annie's Dance & \\
& Cool Breeze & \\
& School Days & \\
& That's All & \\
& Stablemates & \\
& Groovin' High & \\
&
\end{tabular}

the melody orchestrated for a few soloists or the entire band, improvised solos (with band interludes), a shout chorus, and a restatement of the melody. As in bebop, the repertoire is a mixture of newly composed music and arrangements of standards from the so-called Great American Songbook. A hint of Gillespie's humor can also be heard in the band's novelty composition, "Hey Pete! Let's Eat More Meat."

The LPs emphasize their connection to State Department tours at every level of design. ${ }^{26}$ For example, one title portrays Gillespie as a diplomat, and the other places him in a location where he performed in his official capacity. The cover of World Statesman displays his silhouette with a plumed knight's helmet at his feet, a subtle allusion to a history of citizenship and military conflict in Europe and the United States. On the cover of Dizzy in Greece, Gillespie leans against a temple pillar dressed in a white fustanella, the Greek traditional men's costume. He also wears a pair of thick-rimmed sunglasses that subtly recall his hipster look from the 1940s.

The two unadorned back covers feature liner notes in the same organizational pattern. Written by Marshall Stearns, both liner notes recount the band's general activities in Eastern Europe and the Middle East through personal anecdotes and local newspapers reports and then briefly describe the musical content. ${ }^{27}$ The notes to Dizzy in Greece focus on a specific event in Athens, which Stearns describes as the band's greatest diplomatic moment:

${ }^{26}$ The permission fee for the LP cover images prohibits their inclusion in the article. However, each cover is easily found on the web through a keyword search of its title or on its Wikipedia page.

${ }^{27}$ Stearns's personal papers about the State Department tours included several dozen newspaper clippings from the United States and cities the band visited. See clippings in b11 f33, MSC. 


\begin{abstract}
The band reached its peak, musically and diplomatically, in Athens where it out-rocked the rock-throwing Greek students. John "Dizzy" Gillespie and his ambassadors of jazz arrived just after the riots of May, 1956, and anti-American feeling was intense. Right or wrong, the Greeks felt that the United States should help them take Cyprus back from the British. ${ }^{28}$ Newspapers were asking why the Americans were sending jazz bands instead of guns. And the opening concert was staged for the same students who threw rocks at the windows of the United States Information Service.

It was a tense moment and the students jeered as the band started to play. Then silence. And then, a complete and riotous switch — the roar of approval drowned out the big band; hats, jackets, and whatnot were tossed at the ceiling; and even the local gendarmes danced in the aisles. Between numbers, Gillespie miraculously kept the kids under control. After the concert, they carried him out on their shoulders, chanting "Dizzy, Dizzy, Dizzy," stalling traffic for a half hour and a dozen blocks. This music spelled out the happy, friendly, and generous side of American life with explosive force and, incidentally, siphoned off a Niagara of excess energy. ${ }^{29}$
\end{abstract}

By locating the band in Greece, both in title and tale, the LP calls attention to the music's potential to dispel violent tendencies and overcome perceived differences. ${ }^{30}$ Peaceful excitement is key to Stearns's narrative. The stories of the students dancing in the aisles with the authorities and then carrying Gillespie into the street portray a moment of shared jubilation. Placed before the more typical descriptions of the musical content on the record, Stearns introduces the music through its ambassadorial function in order to show the positive outcome of music merged with diplomacy.

The carefully crafted packaging of both LPs told a particular story of jazz that garnered value both in the music's state-sanctioned status and its success with audiences abroad. Although not unprecedented, the explicitly political design was unusual for the time and a product of the technological moment in the jazz industry when record companies were selling more discs and making greater profits than ever before. According to the New York Times, from 1947 to 1957 industry-wide sales nearly doubled, from $\$ 203$ to $\$ 360$ million. At the same time, the longplaying record (LP), which Columbia Records introduced in 1948, was becoming

${ }^{28}$ Cyprus, then a British Crown colony, was seen as a strategic military and economic stronghold for Cold War operations in the Middle East. Seeking to suppress a growing separatist movement, Britain announced its plan to execute two Greek Cypriots it labeled "terrorists" on 8 May 1956, mere days before Gillespie arrived in Athens. The announcement catalyzed riots on 9 May in Salonika outside the British Consulate as well as in Athens, where protestors threw rocks and attempted to storm the office of the USIA because of the continued U.S. support of Britain. Undeterred, the British government executed the two men on the morning of 10 May. Gillespie's band performed for an audience that largely supported Cypriot independence a few days later. The events made front-page headlines in the United States. See "Rioters in Athens Stone U.S. Office," New York Times, 10 May 1956, 1. For more background about the conflict see Brendan O'Malley and Ian Craig, The Cyprus Conspiracy: America, Espionage, and the Turkish Invasion (New York: I. B. Tauris, 1999), 3-34.

${ }^{29}$ Stearns, liner notes to Dizzy in Greece.

${ }^{30}$ As historian Andrea Franzius details, official reports and dispatches from the U.S. embassy in Athens contradict Stearns's characterization of Gillespie's reception, describing the concerts as a "relative non-success" that did not positively influence the political conflict. See Andrea Georgia Marina Franzius, "Soul Call: Music, Race, and the Creation of American Cultural Policy" (Ph.D. diss., Duke University, 2006), 436. 
a dominant format. ${ }^{31}$ Between 1954 and 1956, unit sales of the LP rose from 11.1 to 33.5 million, resulting in a significant increase in percentage of industry sales, from $30 \%$ in 1953 to $61 \%$ in $1957 . .^{32}$ The durable "vinylite" material of the LP could accommodate nearly three times the number of grooves per disc compared to the 78-rpm discs of the previous era. These "microgrooves" resulted in longer, uninterrupted playback time, which increased from four minutes per side for a 12-inch 78-rpm record to well over twenty.

During the transition to the LP, record labels increasingly devoted more resources to visual design and layout. More elaborate graphics and cover images, for example, began to replace the simple lettering and often recycled visual themes ubiquitous on records of the late 1940s and early 1950s. Record titles became progressively more poetic and evocative rather than simply descriptive. ${ }^{33}$ The covers of World Statesman and Dizzy in Greece reflect the industry's changing priorities. ${ }^{34}$ For example, the silhouette image of Gillespie that appears on World Statesman was a recycled photo from a 1954 LP titled Trumpet Battle featuring Gillespie and Roy Eldridge ${ }^{35}$ Norgran's use of existing visual material fit within the logic of the early 1950s record industry, when many labels reused visual content among their albums. In contrast to the predominantly unadorned white and blue background of World Statesman, Dizzy in Greece features an edge-to-edge image of Gillespie and his trumpet. The vibrant color of his Greek outfit stands out against the monochromatic yet memorable background of the textured stone columns. ${ }^{36}$

Liner notes developed alongside the industry's adoption of the LP and came to have a ubiquitous presence on records in the 1950s and after. Many of the first liner notes mimicked the accompanying material found on classical 78-rpm albums that emphasized the biography, description, and background of the music

31 The other dominant format of the era was the 45-rpm single, introduced by RCA in 1949 to compete with Columbia's 33 1/3-rpm long-play format. RCA's 45s were seven inches in diameter and held about four minutes per side, making them an ideal format for juke boxes and popular music hits.

${ }^{32}$ Robert Shelton, "Happy Tunes on Cash Registers," New York Times, 16 March 1958. These numbers come from year-end financial statements from Columbia Records as well as statistical data from the American Federation of Musicians and the Record Industry Association of America. Also note that through the 1950s, 45s consistently outsold LPs in terms of unit sales (i.e., number of records sold), yet LPs generally made up a lager percentage of total industry profits since LPs were the more expensive format. Shelton also points out that "A minute of music on a record today costs less than one-third of what it did before 1948 [the year Columbia introduced the LP]." Thanks to Mark Davidson for suggesting an important revision to this discussion.

${ }^{33}$ For example, the titles of Blue Note's first two 12-inch LPs, most likely released in 1953, were Miles Davis, Vol. 1 (BLP 1501) and Miles Davis Vol. 2 (BLP 1502). Compare these titles to two discs from 1957: Sonny Rollins's Newk's Time (BLP 4001) and Horace Silver's 6 Pieces of Silver (BLP 1539). See the numerical and title catalog listings in Michael Cuscuna and Michel Ruppli, The Blue Note Label: A Discography (Westport, CT: Greenwood Press, 2001), 697-99.

${ }^{34}$ For a more extended version of this argument, see Darren Mueller, "At the Vanguard of Vinyl: A Cultural History of the Long-Playing Record in Jazz" (Ph.D. diss., Duke University, 2015), 28-31, 49-111.

${ }^{35}$ Dizzy Gillespie and Roy Eldridge, Trumpet Battle, Clef 730, 1954, LP (12in). Clef was another Granz subsidiary label.

${ }^{36}$ Granz's emphasis on visual design also had precedent. In 1950, he produced a limited edition 78 rpm album titled The Jazz Scene, which matched carefully selected music with the striking photography by Gjon Mili and illustrations by David Stone Martin. The album, originally issued on Mercury, included six 12-inch 78-rpm discs. The Jazz Scene, Mercury 2071, 1950, 78 (12in). 
and artist. ${ }^{37}$ To those conventions, jazz records added personnel listings and other discographical information. As the genre developed, prominent jazz critics such as Leonard Feather, Nat Hentoff, Martin Williams, and Whitney Balliett all began writing liner notes while also writing for the best-known jazz publications. These trends coincided with increased attention to audio fidelity and recording technique as disc jackets began to display words like "high fidelity," "in living stereo," and "360 degree sound." 38 In accordance with these practices, both World Statesman and Dizzy in Greece prominently display the words "A panoramic true HI-FI recording" on the top left of the cover, placed next to the record label logo and catalog number.

Along with this industry-wide change in format and design, cultural mediators such as label owner Granz, producers such as George Avakian, and Newport Jazz Festival co-founder George Wein increasingly targeted white middle-class audiences. ${ }^{39}$ Granz issued records featuring Ella Fitzgerald singing popular standards accompanied by strings and placed his profitable Jazz at the Philharmonic (JATP) tours in large concert halls. ${ }^{40}$ As the head of popular albums at Columbia Records, Avakian maintained an active jazz roster and successfully produced several crossover records featuring Dave Brubeck, Benny Goodman, Duke Ellington, Louis Armstrong, and Miles Davis. By co-founding the Newport Jazz Festival, Wein brought jazz to the affluent enclave of Newport Beach, Rhode Island. In 1956, the board of directors even changed the name of the festival (and its associated non-profit) to "The American Jazz Festival" and began referring to jazz as "a true American art form" in its promotional materials. ${ }^{41}$ Around this time, the festival also gave the Voice of America broadcasting agency license to record and broadcast from the Newport grounds. ${ }^{42}$

Against this backdrop, Granz founded Verve Records in 1956 with his eye toward the popular music market. ${ }^{43}$ Granz initially conceived of Verve as a vehicle for Ella

${ }^{37}$ Brian Priestley, liner notes to The Jazz Scene, Verve 314521 661-2, 1994, CD.

${ }^{38}$ The term "Living Stereo" appeared on RCA discs in the late 1950s. Columbia Records displayed "360 degree sound" on their LPs beginning in the mid-1950s. The term "high fidelity" or "hi fi" became an industry buzzword during the same time. The wide use of the term led to, among other things, the adoption of this phrase for the well-known periodical High Fidelity, a magazine founded in 1951. For an overview see David Morton, Sound Recording: The Life Story of a Technology (Westport, CT: Greenwood Press, 2004), 129-40.

${ }^{39}$ Davenport, Jazz Diplomacy, 43; Monson, Freedom Sounds, 12.

${ }^{40}$ Granz began JATP in 1944 in Los Angeles. He expanded the concert series into a nationwide tour in the mid-1940s and, eventually, to Europe as well. The tours were also known for being racially integrated on stage and for Granz's insistence on desegregated audiences. See Tad Hershorn, Norman Granz: The Man Who Used Jazz for Justice (Berkeley: University of California Press, 2011), 96-110.

${ }^{41}$ Minutes, Special Meeting of the Members of The Jazz Festival of Newport, R.I., Inc., 19 January 1956, box 2 folder 4, The Newport Jazz Festival Records (MC 038), Institute of Jazz Studies, Rutgers University Libraries.

${ }^{42}$ For a detailed account of the mainstreaming of jazz at the Newport Jazz Festival, see John Gennari, Blowin' Hot and Cool: Jazz and Its Critics (Chicago: University of Chicago Press, 2006), 207-15, 225-49. For more on contestations over racial politics at Newport, see Scott Saul, Freedom Is, Freedom Ain't: Jazz and the Making of the Sixties (Cambridge, MA: Harvard University Press, 2003), $123-43$.

43 "Granz Forms Two Labels, Dickers for Mars Masters, Cuts EP Price," Down Beat, 8 February 1956, 8. The article quotes Granz describing the artists on this new label as ones with "commercial possibilities" and the promotional strategy that would be "necessary for a pop line." 
Fitzgerald, whom Granz had been managing since the mid-1940s. ${ }^{44}$ Fitzgerald's early LPs on Verve each featured the repertoire of a different composer of the Great American Songbook. This organizational strategy took advantage of the 12-inch LP's capacity, which allowed for a single theme to be sustained through twenty-two minutes of uninterrupted music per side. ${ }^{45}$ Granz succeeded beyond expectation. Ella Fitzgerald Sings the Cole Porter Song Book, one of Verve's first LPs, became Fitzgerald's first top-selling record when it reached the number one position on the jazz charts in August 1956, several months before the release of Gillespie's World Statesman. ${ }^{46}$ Between July 1956 and June 1957, Fitzgerald's Verve records overwhelmingly occupied the top position on the jazz bestseller list, while her name started appearing alongside Harry Belafonte, Frank Sinatra, Elvis Presley, and Perry Como as a top "recording personality" of the day. ${ }^{47}$

Verve's attempt to package jazz toward a broader audience was a success, at least financially. The label earned an estimated $\$ 2$ million in sales in its first year and in 1957, Granz decided to unify his other labels, including Norgran and Clef, under the Verve banner. ${ }^{48}$ All subsequent Gillespie titles, including Dizzy in Greece, appeared under the Verve imprint. The label also reissued many LPs from Norgran's catalogue, usually with no changes except an updated logo on the top right-hand corner of the album cover, as was the case with World Statesman.

The circulation of World Statesman and Dizzy in Greece coincided with Verve's founding, the record industry's total growth, and the rapidly expanding popularity of the LP format. The increased emphasis on the details of visual design-larger cover photos, more vibrant colors, the space for liner notes-made records audiovisual media. Using Norgran and then Verve as his platform, Granz took advantage of these industry changes to capitalize on Gillespie's role with the State Department and insert jazz into national debates about cultural diplomacy during the Cold War.

\section{Gillespie's LPs and the Concert Tours}

Both LPs explicitly equate the musical contents of the discs to the concert tours through the liner notes. "This album," Stearns writes on World Statesman, "furnishes a sampling — volume two is yet to come-of the first half of the concert with Gillespie at his all-time best." He classifies two pieces as "encores" and eventually

${ }^{44}$ Granz signed Fitzgerald away from Decca, the label Fitzgerald had been with for twenty years. See "Fitzgerald to Granz Label," Down Beat, 8 February 1956, 8. The article describes Verve as Granz's "pop company."

${ }^{45}$ Granz's interest in creating concept albums went back to the early 1940s. The first recordings of the Jazz at the Philharmonic concert series, for example, were placed in multi-disc 78-rpm albums that included detailed descriptions of the concert, including personnel and solo order: Jazz at the Philharmonic: Presented by Norman Granz, Stinson Records S453, 1945, 78 (12in).

46 "Ella: It Took a Hit Album to Make Miss F. a Class Nitery Attraction," Down Beat, 28 November 1956, 13.

${ }^{47}$ After several months at number two, Fitzgerald's Cole Porter record reached the top bestseller spot in August 1956. Her other bestselling records featured the music of Richard Rodgers and her duets with Louis Armstrong. See "Best Sellers" in Down Beat between July 1956 and June 1957. The "recording personality" list comes from a disc jockey poll. See "1957 Deejay Poll," Down Beat, 30 May 1957, 12.

48 “Granz Unifies Four Disc Series under Verve Banner,” Down Beat, 20 February 1957, 10. 
concludes, "So ends the first album and the first half of the concert." The notes on Dizzy in Greece take a similar approach: "This is the second album (the first was Dizzy Gillespie: World Statesman) of the music that piled up friends and momentum as it swung through the Middle East." 49 To introduce his discussion of the music, Stearns writes, "The concert begins with the novelty HEY PETE, a Quincy Jones arrangement of the blues." A draft of Stearns's liner notes to Dizzy in Greece concludes with a short statement, "The concert is over." Though eventually cut, the sentence was meant to parallel the end of the notes on World Statesman..$^{50}$

Surviving programs from Gillespie's Middle East tour make it clear that the LPs contain only a portion of the actual concert repertoire. Whereas the LPs features bebop-inspired arrangements of standards and original compositions orchestrated for the entire band, the Middle East tour concerts presented a much more varied selection of styles and ensemble configurations (Figure 1). ${ }^{51}$ The first half of the concert featured a succession of performances intended to present an overview of jazz's historical development. ${ }^{52}$ The band's two vocalists, Dottie Saulters and Herb Lance, neither of who appear on the LPs, sang African American spirituals, and Gillespie and drummer Charlie Persip demonstrated "African drum rhythms." ${ }^{33}$ The ensemble also performed various examples of blues and early jazz styles, including a Dixieland rendition of "When the Saints Go Marching In" and several note-for-note transcriptions of pieces from the swing bands of Jimmy Lunceford, Duke Ellington, Benny Goodman, and Count Basie. .5 "Groovin' High" concluded the concert's first half as an example of the bebop style that Gillespie had helped make famous. The second half highlighted the band's modern repertoire and included several Gillespie originals: "Cool Breeze," "The Champ," and "A Night in Tunisia." Along with various small group tunes, presumably played in the bebop style, the band also performed swing-era vocal numbers such as "Seems Like She Just Don't Care" and "Gimme a Little Kiss."

This programming served several purposes. The historical material educated audiences unfamiliar with the many types of jazz and its development. ${ }^{55}$ Presenting

\footnotetext{
${ }^{49}$ Stearns, liner notes to World Statesman. Notice also that both records mention the other despite being issued a year apart.

50 "Dizzy in Greece-Vol. II," typed draft, b20 f1, MSC.

${ }^{51}$ Greece Concert Program, b24 f22, and "Dizzy Gillespie and His Orchestra: Program," typed document, b24 f22, MSC. The 2 May 1956 issue of Down Beat gives a similar account. See "History of Jazz Big Feature of Gillespie Overseas Tour," 9. In the scholarly literature about Gillespie's tours, only Monson and Fosler-Lussier mention the content of the band's performances: Monson, Freedom Sounds, 115-16; Fosler-Lussier, Music in America's Cold War Diplomacy, 80-82.

${ }^{52}$ Greece Concert Program, MSC. This concert format was also described in the jazz press. See "History of Jazz Big Feature of Gillespie Overseas Tour."

${ }^{53}$ Persip and Gillespie's demonstration was likely a variant of West African drumming styles that Gillespie had adopted into his playing via his interest in Afro-Cuban music and collaborations with Cuban percussionist Chano Pozo. For more on the cultural politics of Gillespie's Afro-Cuban styles, see Jairo Moreno, "Bauza-Gillespie-Latin/Jazz: Difference, Modernity, and the Black Caribbean," South Atlantic Quarterly 103, no. 1 (2004). 16.

${ }^{54}$ Marshall Stearns, “Turkey Resounds, Reacts to Dizzy Gillespie Band,” Down Beat, 27 June 1956,

${ }^{55}$ As Down Beat reported in May 1956, Gillespie did this to "demonstrate the evolution of big band" and "summarize several significant jazz trumpet styles." See "History of Jazz Big Feature of Gillespie Overseas Tour.” Also see Standalone photo, New York Amsterdam News, 7 April 1956, 16.
} 


\section{DIZZY GILLESPIE AND HIS ORCHESTRA}

$P R O G R \wedge M$

St. Louis Blues

African Drum Rhythrs

Spiritua!s

Sometimes I Feel like a Motherless Child

Joshua Fit the Battle of Jericho

Oldtime Blues

Dixieland: When the Sain's Go Marching In

New Orleans: Armstrog's Im Confessin

S w ing: Ellington's Mood Indigo,

Luncefords For Dancers Gily

Goodman's King Porter stomp

Eldredge's Rockin Chair

Basie's One O Clock Jumpi

B o p: Groovin High ne Whispering
Orchestra

Dizzy Gillespie

Herb Lance

Dizzy Gillesp'e

Small Pand

Dizzy Gillespie

Orchestra

Orchestra

Orchestra

Orchestra

Or.hestra

Gillespie and Orchestra

\section{N T E R M I SSION}

Cool Breeze

Orchestra

Stella by Starlight . . . . . . Dizzy Gillespie and Orchestra
Night in Tunisia
Orchestra

Vocals by Herb Lance accompanied by the Orchestra

Lucky Old Sun

Seems Like She Just Don't Care

The Gillespie Small Band

Shoo Be Doo Be

Begin the Beguine

Sunny Side of the Street

The Champ . . . . . Orchestra with drum solo by Charles Persip

Vocals by Dotte Saulters accompanied by the Orchestra

Make Love to Me

The Birth of the Blues

Gabriel ( a spiritual)

Gimme a Little Kiss . . . Gillespie and Dottie Saulters

I Want You be My Baby

. Gillespie and Orchestra

Figure 1. (Color online) Concert program from Greece tour, 1956. Program and notes, box 24, folder 22, 1956 Dizzy Gillespie Tour of the Near East, the Marshall Winslow Stearns Collection (MC 030), Rutgers University Libraries, Institute of Jazz Studies.

the wide variety of sub-styles and reenacting historical big band charts told a musical story that started with jazz's earliest roots and arrived at Gillespie's modern style. Although jazz performance has always been historically self-referential, the explicit recreation of earlier styles was unusual in the mid-1950s. ${ }^{56}$ This concert

\footnotetext{
${ }^{56}$ The emulation of historical styles occurs throughout a jazz musician's training, although not usually as a note-for-note onstage performance. More on this practice and its history can be found in
} 
programming, originally a suggestion of Marshall Stearns, taught audiences various aspects of the music in an easily digestible narrative of progress and arrival. ${ }^{57}$

In South America, where the band traveled to Ecuador, Argentina, Uruguay, and Brazil, the ensemble abandoned the historical portion of the program and added several newly composed arrangements in Gillespie's Afro-Cuban jazz style. ${ }^{58}$ Along with performing "Manteca" and "Tin Tin Deo," the ensemble's versions of "Begin the Beguine" and "Flamingo" also included newly arranged sections that heavily featured Afro-Cuban jazz rhythms. While on tour, the band also sought opportunities to play with famous tango artists in Buenos Aires and samba musicians in Rio de Janeiro. Argentinean pianist and future Hollywood composer Lalo Schifrin and trumpeter Franco Corvini were invited to travel and perform with the band as well. The hybrid musical styles showcased how jazz could be combined with other American musics, while the invitations for local artists to join the band demonstrated the musicians' propensity for inclusivity and diversity.

The band's activities in South America were not included on the commercially produced LPs from the late 1950s. Record producer Dave Usher, a friend and former business partner of Gillespie's, accompanied the band in South America and recorded every concert the band played using a portable suitcase tape recorder. ${ }^{59}$ According to Usher, he and Gillespie hoped the tapes might interest Granz on their return to the United States. Granz declined, but Usher kept the tapes, eventually issuing twenty-eight tracks across three CDs in 1999 and $2001 .^{60}$ The accompanying liner notes and credits include neither specific dates nor locations, yet the music remains consistent with several other live recordings of Gillespie's band from the same time period, including a Verve LP from the 1957 Newport Jazz Festival. As such, Usher's recordings give a sense of how Gillespie's band likely sounded during both tours.

A version of "Groovin' High" recorded on location in South America illustrates how the band brought jazz history into the present through performance. ${ }^{61}$ The ambassadorial band's arrangement pays tribute to Gillespie's bebop collaboration

Paul Berliner, Thinking in Jazz: The Infinite Art of Improvisation (Chicago University of Chicago Press, 1994), 64-65, 101-9, 237-38.

${ }^{57}$ Dave Usher first suggested to me that the idea of historical re-enactment came from Stearns. This was later confirmed in the archives in a 1963 letter to the director at the Bureau of Cultural Affairs. Stearns to Glenn G. Wolfe, 6 March 1963, b10 f29, MSC. Dave Usher, telephone interview with the author, 9 July 2015. The same argument can also be found in Fosler-Lussier, Music in America's Cold War Diplomacy, 79-84.

${ }^{58}$ Although I have not been able to locate surviving programs from South America, several recordings of Gillespie's tour in that region survive: Dizzy Gillespie, Dizzy in South America Official U.S. State Department Tour, 1956: Volume 1, Consolidated Artists Production CAP 933, 1999, CD; Dizzy Gillespie, Dizzy in South America Official U.S. State Department Tour, 1956: Volume 2, Consolidated Artists Production CAP 934, 1999, CD; Dizzy Gillespie, Dizzy in South America: Volume 3, Consolidated Artists Productions CAP 935, 2001, CD.

${ }^{59}$ In the early 1950s, Usher and Gillespie founded the short-lived Dee Gee Records.

${ }^{60}$ For details see footnote 55. Usher remembers using an Ampex 600 tape recorder, which came in two pieces surrounded by Samsonite luggage. Usher, interview with the author. These details are confirmed in Maggin, Dizzy, 283-84.

${ }^{61}$ My reading of the history and performance is influenced by Diana Taylor's notion of the "historically charged" present of live performance. Diana Taylor, The Archive and the Repertoire: Performing Cultural Memory in the Americas (Durham, NC: Duke University Press, 2003), 143. 
with Charlie Parker: the melodic content of the ensemble tags, solo transitions, and coda material, as well as the orchestration of the melody-unison trumpet and alto saxophone-originate from Gillespie and Parker's 1945 recording. ${ }^{62}$ Gillespie based the harmony of "Groovin' High" on a well-known standard from the 1920s titled "Whispering." The concert program alluded this practice by expanding the title to "Groovin' High ne [sic] Whispering." 63 To make this historical connection aurally explicit, the saxophone section overlaid the original melody of "Whispering" (played in unison) onto Gillespie's composition (beginning at 0:30). Although bebop musicians often employed the harmony of songbook standards in this way, it was unusual to perform the original and newly composed melodies simultaneously.

In his demonstration of New Orleans jazz, Gillespie imitates the vocal and trumpet styling of Louis Armstrong on the band's version of "I'm Confessin'" ${ }^{4}$ During the spoken introduction and vocal scat breaks of the South American performance captured on Usher's tapes, Gillespie expertly mimics Armstrong's voice. For example, when Gillespie sings the word "but" he places a strong attack on the "B" in an Armstrong-like gesture (0:54). At other points, he imitates the elder trumpeter's propensity to end phrases with a long, sung "mmmmm" (0:17). Gillespie's trumpet style also pays tribute through half-valve attacks, shakes at the ends of phrases, extended high notes, and quotations of the song's melody. Fast bebop lines are notably absent. With its combination of humor and skill, the performance elicits laughter and strong applause from the audience. ${ }^{65}$

"I'm Confessin" concludes with a lengthy call and response between soloist and band. Gillespie executes a series of rising high notes (2:15):

Gillespie plays: $\mathrm{Ab}-\mathrm{Ab}-\mathrm{C}-\mathrm{Ab}-\mathrm{C}$

Persip: Snare and bass drum hit. [pause] Band members: "Higher!"

Gillespie: Ab-C-C\#-A-C\#

Persip: Snare and bass drum hit. [pause] Band members: "Higher!"

Gillespie: A-C\#-D-Bb-D

Persip: Snare and bass drum hit. [pause] Band members: "Higher!"66

At this point, the melodic ascent ends and Gillespie holds his high D. Responding to another call for "higher," he whistles the next note in the series; the audience

\footnotetext{
${ }^{62}$ For more about the historical moment of this recording, see Scott DeVeaux, The Birth of Bebop: A Social and Musical History (Berkeley: University of California Press, 1997), 364-65.

${ }^{63}$ Bebop musicians often composed new melodies over the chord progressions of well-known standards. Famous examples include Tadd Dameron's "Hot House" ("What is This Thing Called Love”); Miles Davis's “Dig” (“Sweet Georgia Brown”); and Charlie Parker's "Anthropology” ("I Got Rhythm"). Other arrangements in Gillespie's tour repertoire were derived from existing material, including two Melba Liston arrangements. She based "Annie's Dance" on the third movement of Edvard Grieg's Peer Gynt Suite no. 1 op 46. Leonard Feather, "This Melba Is a Peach,” Down Beat, 16 September 1956, 16. Liston's "My Reverie" was based on a theme composed by Claude Debussy. Stearns, liner notes to World Statesman.

${ }^{64}$ Gillespie, Dizzy in South America, Volume 2. The version mentioned here closely follows a 1952 recording of Gillespie's called "Pop's Confessin'”

${ }^{65}$ Two examples (of many) occur at 0:17 and 0:39.

66 The pitches I've listed here are as they sound (in concert pitch) on the recording.
} 
laughs and cheers in response. Still in character, Gillespie starts chanting, "Gotta get one of those high Cs with the red beans and rice" and "high C, let's see, let's see where the high C is. Mmmmm" (2:52). He continues until the piano player answers a particularly loud outburst of "AHHHH" from Gillespie by playing the target, one step above Gillespie's last played note (3:32). After a few more moments of chatter, Gillespie asks the band, "You ready boys? Go ahead." Another band member responds, "Are you ready?", and Gillespie nearly breaks character before repeating his question. His final $\mathrm{Ab}-\mathrm{Ab}-\mathrm{Db}$ releases the built up tension and concludes the performance. Gillespie reclaims his regular stage voice to announce the next tune.

Gillespie's intelligence as a comedian and exuberant, onstage charisma were major reasons the musical advisory panel recommended him to the State Department in $1956 .{ }^{67}$ With roots in the slapstick comedy of vaudeville, this jokester persona was an extension of the theatricality of other bandleaders such as Cab Calloway, who employed Gillespie between 1939 and 1941. Such onstage antics were, in fact, what gave him the nickname "Dizzy" during his time in the Frankie Fairfax band in the mid-1930s. Gillespie's expertly crafted version of Armstrong brought levity to a performance that originated from worldwide contestations over democracy and communism.

By matching novelty tunes, musical gags, and jokes with high-level musicianship, Gillespie offered an accessible and engaging performance to an audience unfamiliar with jazz. Several newspaper and magazine articles remarked on the overwhelming audience response. The Pittsburgh Courier, for example, characterized the reaction in Abadan, Iran, as a "miracle" when the audience began "awkwardly" clapping along. "Soon," the article continues, "whistles and screams reached the stage." 68 Stearns similarly reported that in Aleppo, Syria, some audience members would yell phrases like "rock it and roll it," while others would "clap on the wrong beat, trying to figure out the proper response." 69 In Ankara, Turkey, the band was "drowned out by the roar of the audience" that was "a solid wall of sound." 70 Photos from the Middle East tour display large, over-packed concert halls with people visibly yelling, whistling, and dancing in the aisles. ${ }^{71}$ Usher recalled a similar scene in South America, a claim substantiated by the audience on his recordings. ${ }^{72}$

Gillespie's skill and flexibility exhibited an authority over the concert hall. Stearns describes how the "pandemonium" of the audience "ground to a halt only when the

\footnotetext{
${ }^{67}$ Monson, Freedom Sounds, 113. In a 1956 concert review, Hentoff similarly praised Gillespie's "unquenchable wit" and ability to combine "authority with good humor" while fronting the band. Hentoff, "Dizzy Gillespie Orchestra: Birdland, New York."

68 "Indians Dizzy over Gillespie’s Jazz: Part 1,” Pittsburgh Courier, 2 June 1956, 22.

${ }^{69}$ Marshall Stearns, “Dizzy's Troupe Casts Spell over Mideast Audiences,” Down Beat, 17 June 1956, 16; Stearns, “Turkey Resounds, Reacts to Dizzy Gillespie Band.” The articles also include several lengthy passages from alto saxophonist Phil Woods, who similarly comments on the audiences' enthusiasm.

${ }^{70}$ Stearns, “Dizzy's Troupe Casts Spell over Mideast Audiences," 17.

${ }^{71}$ Concert photos, Istanbul and Athens, b15 f10, MSC.

${ }^{72}$ Usher, interview with the author.
} 
band started the Turkish national anthem followed by the Star Spangled Banner."73 The New York Amsterdam News and the Pittsburgh Courier similarly reported on the positive reaction to the band's performance of the Iranian national anthem. ${ }^{74}$ Together, the paired anthems performed a notion of unity, a sentiment further accentuated by bilingual programs. ${ }^{75}$ Writing for Down Beat, Stearns expressed the "pleased confusion caused by the fact that there are white as well as colored musicians in the band." He also characterized the reactions of people across a wide spectrum of age, ethnicity, and nationality as "something universal." levels, the concerts challenged audiences to re-evaluate any preconceived notions of institutional racism within the United States. After all, how were these audiences to understand a black bandleader who spoke freely about racial politics and employed white musicians? ${ }^{77}$

Even as these onstage actions pushed a narrative of progress toward an egalitarian future, Gillespie's emphasis on blues traditions, church spirituals, and the styles of New Orleans, Dixieland, and swing placed jazz within a historical trajectory of African American music. At the same time, the "African drumming" demonstration overtly tied the music to the transatlantic movement of African peoples through slavery. ${ }^{78}$ Repurposing jazz history into the present shrewdly told a story that tied U.S. music to African American expressive culture. Through humor, playfulness, and musical expertise, Gillespie's onstage actions presented U.S. culture as inherently hybrid, diverse, and multinational. In doing so, he skillfully navigated an ideological space layered with politically charged discourses about communism, racism, and democracy. ${ }^{79}$

The LPs served a different purpose, as evidenced by the re-organization of materials as well as the musical minutia. Unlike the State Department tour concerts, the LPs included neither small group performances nor big-band vocal tunes. Gone too were the demonstrations of jazz's historical development and Gillespie's antics, jokes, and displays of humor meant to engage with audiences. Though the back of

73 Stearns, “Turkey Resounds, Reacts to Dizzy Gillespie Band.” The liner notes to World Statesman similarly state that, at the end of one concert, "a quick encore of the current country's national anthem was necessary to restore order." Stearns, liner notes to World Statesman.

74 "Indians Dizzy over Gillespie's Jazz: Part 1"; Standalone photo, New York Amsterdam News.

${ }^{75}$ Stearns's papers include concert programs and lecture notes in English, Turkish, Bosnian (and/or Croatian), Arabic, and Greek. See the lecture handouts, outlines, notes and concert programs in b24 f23, b11 f30, b24 f22, MSC. Also see "Dizzy Gillespie and His All Stars Jazz Concert," Concert Program from Abadan, Iran (Taj Theater), March 1956, Gillespie Clippings, IJS.

${ }^{76}$ Stearns, "Turkey Resounds, Reacts to Dizzy Gillespie Band"; Stearns, "Dizzy's Troupe Casts Spell over Mideast Audiences."

${ }^{77}$ For more on Gillespie's view, see Gillespie and Fraser, To Be or Not, 414.

${ }^{78}$ Like many during this time, Stearns and Gillespie were both heavily invested in the narrative of jazz being connected to Africa. For a detailed overview of this position and how the idea of "African retention" often assumes a historically unspecific sense of the continent, see Steven Feld, Jazz Cosmopolitanism in Accra: Five Musical Years in Ghana (Durham, NC: Duke University Press, 2012), 53-78; Robin D. G. Kelley, Africa Speaks, America Answers: Modern Jazz in Revolutionary Times (Cambridge, MA: Harvard University Press, 2012); Moreno, "Bauza-Gillespie-Latin/Jazz"; and Ronald M. Radano, Lying up a Nation: Race and Black Music (Chicago: University of Chicago Press, 2003).

${ }^{79}$ My reading of Gillespie's humor as both a tool for relating across forms of cultural difference and as a mode of social critique is influenced by Glenda Carpio, Laughing Fit to Kill: Black Humor in the Fictions of Slavery (New York: Oxford University Press, 2008), 7. 


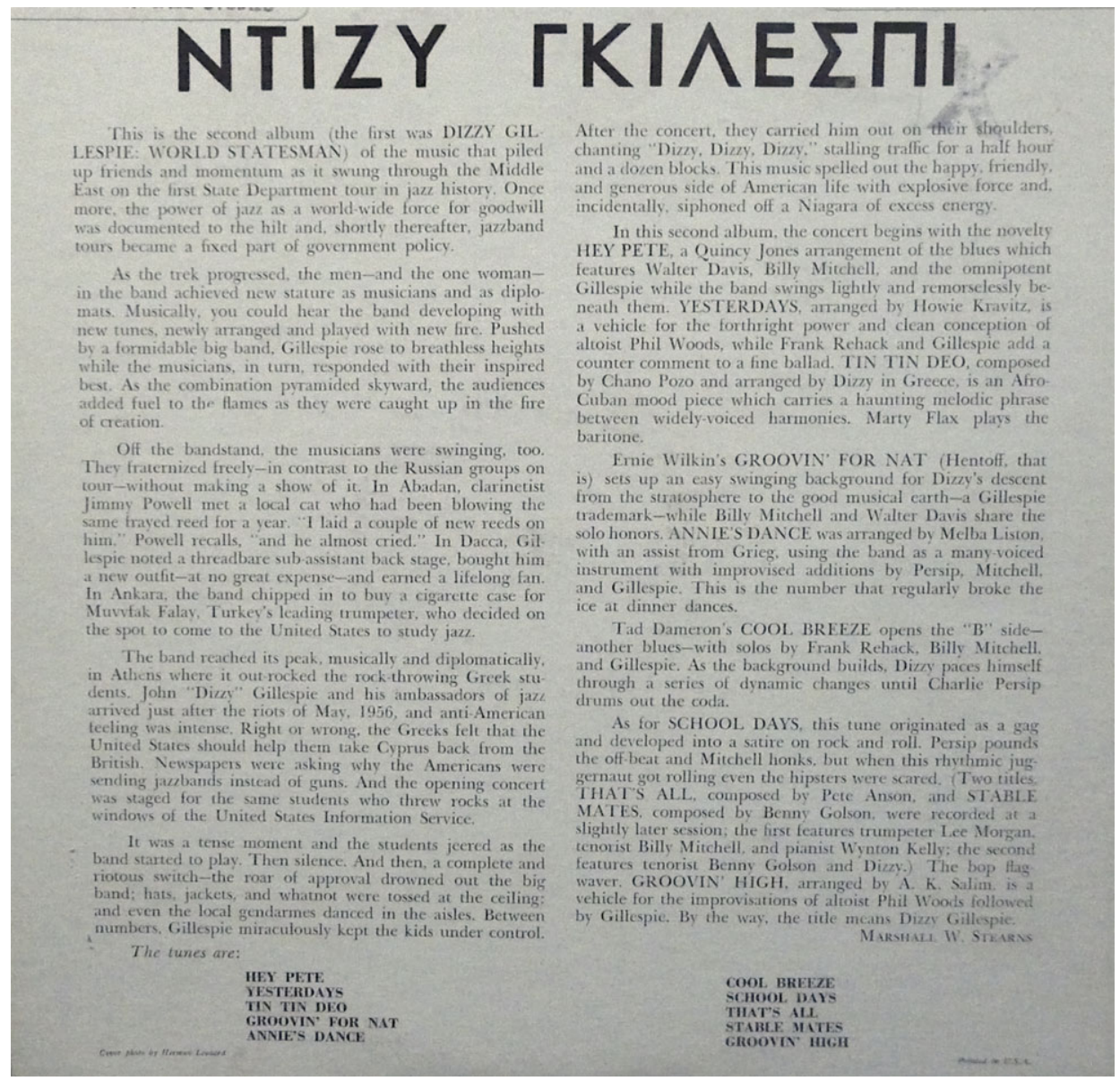

Figure 2. (Color online) Back of jacket with Greek lettering. Dizzy Gillespie, Dizzy in Greece, Verve MV-2630, 1957, LP.

Dizzy in Greece replicated the Greek lettering of Gillespie's name from the concert program (Figures 2 and 3), the LP shared only two titles with the actual Greek performance: "Cool Breeze" and "Groovin' High." 80 The arrangement of "Groovin' High" stayed mostly the same, except that the band omitted the "Whispering" melody meant to illustrate the song's origin.

Commercial considerations partially account for this difference because U.S. consumers were the LPs' target market. Potential buyers would not need to buy a record of Gillespie playing Count Basie, for example, when he or she could easily buy an LP of Basie's own band on the same record label. For their U.S. performance in the middle of 1956, as Nat Hentoff wrote in Down Beat, the ensemble had to scramble for arrangements because "half of the band's overseas program was concerned with a historical recapitulation of jazz, a documentary which would not

${ }^{80}$ Other songs from the concert program appear on World Statesman, including "Stella by Starlight," "Night in Tunisia," and "The Champ." 


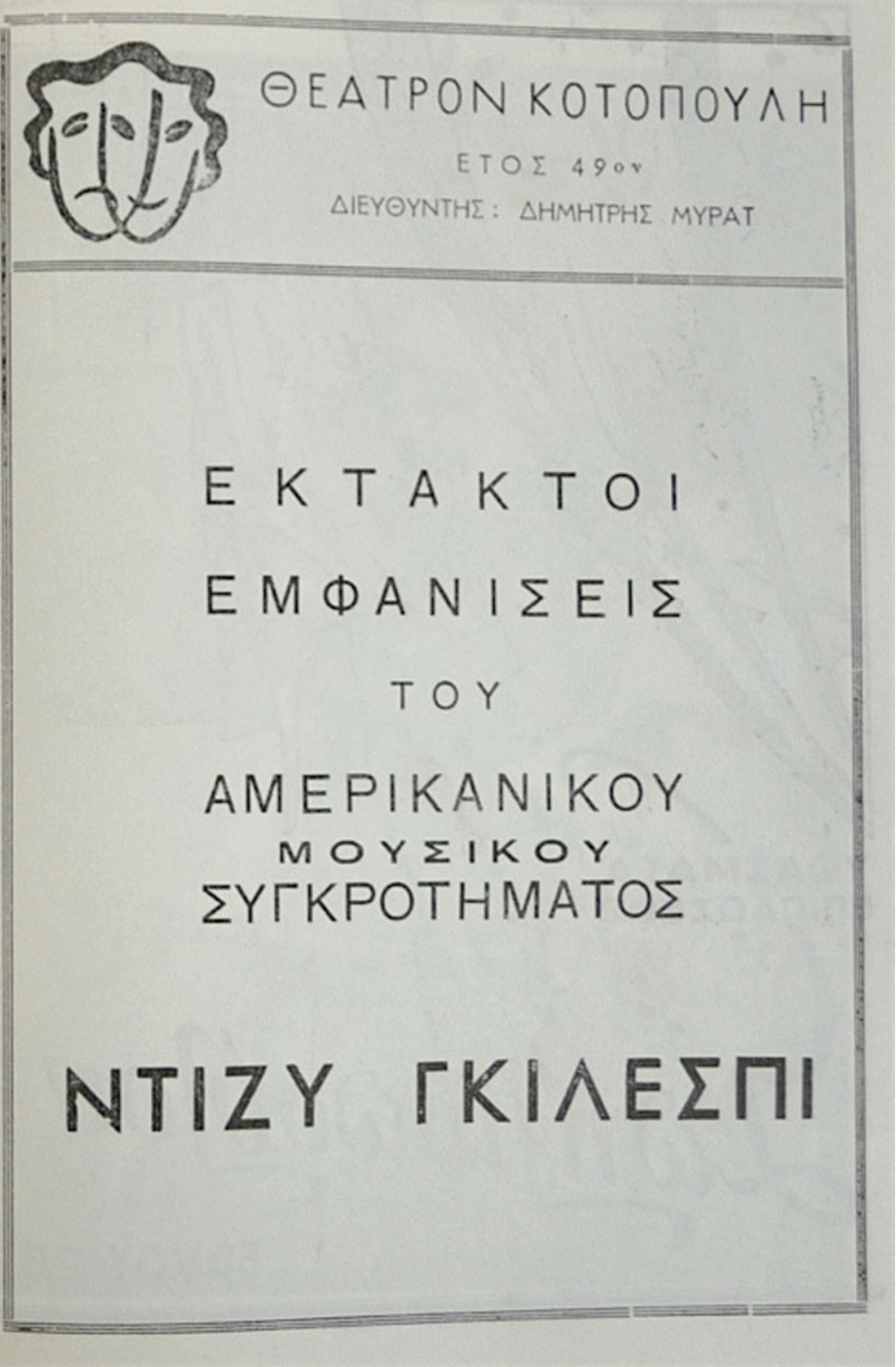

Figure 3. (Color online) Concert program title page, 1956. Concert program (Greece), box 24, folder 22, 1956 Dizzy Gillespie Tour of the Near East, the Marshall Winslow Stearns Collection (MC 030), Rutgers University Libraries, Institute of Jazz Studies.

have been usable for American club dates." 81 The LPs' target audience paralleled that of the club date Hentoff mentions.

However, market factors do not completely explain the dissimilarities between Gillespie's ambassadorial LPs and the tour concerts. After all, another Verve LP

${ }^{81}$ Hentoff, "Dizzy Gillespie Orchestra: Birdland, New York.” 
from 1957 featuring the same ensemble, Dizzy Gillespie at Newport, includes several moments of Gillespie's musical humor and onstage antics. ${ }^{82}$ The band's Newport rendition of "Doodlin'," for example, ends with an impromptu call and response between band members. During the restatement of the theme at the end of the chart, baritone saxophonist Pee Wee Moore purposefully misplays his highly exposed melodic line. Pianist Wynton Kelly responds with a jagged extrapolation of the melody; the band laughs and Gillespie shouts, "Hey!" (5:23). Moore plays his melody again with an over-exaggerated vibrato, as if mocking Gillespie. The rest of the band mimics this humorous vibrato, creating a noticeable reaction from the Newport audience (6:24). ${ }^{83}$

By omitting the moments of humor, spoken introductions, and interactions with the audience, World Statesman and Dizzy in Greece present Gillespie's music as serious political work. The second LP, Dizzy in Greece, for example, placed the band within the cradle of white European civilization, visually accentuated by the photo of Gillespie adorned in the white fustanella and positioned against the Greek temple columns. ${ }^{84}$ While the tour concerts told a story about jazz, racial progress, and the importance of African American music to U.S. culture, the LPs removed any direct ties to African American expressive culture by omitting the performances of African drumming, African American spirituals, blues practices, and New Orleans second line traditions. The "whitewashing" of the band's activities on tour presented jazz to white, mainstream U.S. audiences by adopting a language of racial uplift and respectability. In doing so, the LPs appealed to Western European values of concert music through their audiovisual production and design.

\section{Marshall Stearns Drafts his Liner Notes}

The aggressively uneven political climate in which jazz operated at this time was on display during three congressional hearings in June and July of 1956. Representative John Rooney and Senator Allen Ellender, in particular, forcefully questioned Theodore Streibert, director of the United States Information Agency (USIA) and coordinator of the Cultural Presentations program, about the validity, effectiveness, and cost of the jazz programming. ${ }^{85}$ During the House Appropriations Subcommittee meeting, Rooney pointedly asked Streibert about Gillespie, "Do you think it is a good expenditure of Government funds to allocate $\$ 5,000$ in connection with Dizzy Gillespie?" After correcting the dollar amount, Streibert spoke positively about the

${ }^{82}$ Dizzy Gillespie, Dizzy Gillespie at Newport, Verve MG VS-6023, 1957, LP (12in). Verve also issued three tracks of the band's Newport performance on a different LP featuring Count Basie, Mary Lou Williams, and Joe Williams.

${ }^{83}$ A similar (and even longer) version of "Doodlin" can be heard on Gillespie, Dizzy in South America, Volume 2.

${ }^{84}$ The cover photo was likely taken in the United States after the tour since there is no account of the photographer, Herman Leonard, traveling with the band. Surviving photos from Greece do portray Gillespie standing next to noticeably decaying columns, though none with him in a fustanella. See the prints and concert photos in b15 f6, b15 f10, MSC.

${ }^{85}$ For the full testimony, see The Supplemental Appropriation Bill, 1957: Hearings before Subcommittees of the Committee on Appropriations, House of Representatives, Eighty-Fourth Congress, Second Session, Part 2 (Washington, D.C.: U.S. Government Printing Office, 1956), 702-16, 732-47; and Hearings before the Committee on Appropriations, United States Senate, 468-87. 
first jazz tour: “ $\$ 4,400$, yes. Yes, sir, I think so. There is an enormous interest in American jazz bands, which is a great resource of this country." 86

Unconvinced, the House committee voted to cut the project's proposed budget in half, from 9 to 4.6 million dollars. A few weeks later, on 9 July, Streibert appeared before the Senate Appropriations Subcommittee and asked the Senate to restore the original budget. Resistance came from Senator Ellender of Louisiana:

Ellender: Now, I notice that you have also increased the amount for cultural activities; that is, to send orchestras abroad, and things like that.

Streibert: Yes, sir.

Ellender: Do you think that is beneficial? Let me have it straight.

Streibert: I will say this: I am in the business now of spending money to make an effect on public opinion abroad. I want to say that, in my opinion and from my experience, there is nothing we have spent that has produced such an effect per dollar spent as is sending of orchestras, of performers, of Porgy and Bess, of various kinds of individuals, particularly in the Near East, South Asia, and Far East, as this cultural program. It has paid off big dividends.

Now, I base that on reports from the posts, but I base it also on what our Ambassadors say, not what our own people in the Information Agency tell me, but what Ambassadors report back to the State Department.

Ellender: What reports did you get on the presentation of Dizzy Gillespie's orchestra? I heard it at one of the President's big dinners, I think, and I never heard so much pure noise in my life. They said that they played in Turkey and Rome and Paris, and I am wondering what good you got out of that.

Streibert: Well, sir, jazz is one of our resources. It is one of our assets. We are just starting to use it. We have been using it on the air very successfully in a program of music from America which has been widely listened to in Eastern Europe. ${ }^{87}$

Streibert went on to cite a positive press account as well as a glowing review from a Beirut dispatch. Undeterred, Ellender continued his hardline questioning: ${ }^{88}$

Ellender: Did you get any criticism?

Streibert: No, sir.

Ellender: None whatever?

Streibert: No, sir. There has been criticism that people have been unable to get tickets and get in. They have been very generous in giving extra performances and playing at private affairs. I read the dispatches from Istanbul

\footnotetext{
${ }^{86}$ Hearings before the Subcommittees of the Committee on Appropriations, House of Representatives, 736.

${ }^{87}$ Hearings before the Committee on Appropriations, United States Senate, 482.

${ }^{88}$ As Danielle Fosler-Lussier points out, such reports often painted the cultural programs in a positive light because financial support depended on favorable accounts of progress. Fosler-Lussier, Music in America's Cold War Diplomacy, 3, 229n7.
} 
and they are similarly ecstatic. Not everybody likes jazz. Probably you are among those who do not.

Ellender: It is not a question of liking it. When I first voted for this measure, as you remember 2 years ago, the idea was to put forth that the people of England and France and Western Europe thought we were barbarians. That is in the record. I remember it. And it was brought out that we ought to counter that by sending in our own cultural orchestras and what have you. ${ }^{89}$

Ellender ends this portion of the discussion by unequivocally stating his view: "I say it does more harm than good to send some of this abroad, in my humble judgment." "90 In a press account soon after, he repeated his assertions regarding Gillespie: "To send such jazz as Mr. Gillespie, I can assure you that instead of doing goodwill it will do harm and the people will really believe we are barbarians." Along with his description of Gillespie's music as "noise," Ellender uses language with racist overtones to differentiate jazz from orchestral music, which he finds to have more social and cultural validity.

As this testimony attests, disagreements over the funding for the Cultural Presentations program placed jazz and its practitioners in the middle of a cultural war over domestic and international Cold War policy. For his part, Gillespie embraced the public and highly political platform. In response to negative press reports about the congressional hearings, Gillespie sent a widely publicized telegram to President Eisenhower in August 1956:

\begin{abstract}
Shocked and discouraged by decision of the Senate in the supplementary appropriation bill to outlaw American jazz music as a way of making millions of friends for USA abroad. Our trip thru Middle East proved conclusively that our interracial group was powerfully effective against Red propaganda. Jazz is our own American folk music- the communication with all people regardless of language or social barriers. I urge that you do all in your power to continue exporting this invaluable form of American expression of which we are so proud. ${ }^{92}$
\end{abstract}

Gillespie emphasized jazz's wide popularity across social strata as well as its inherent connections to U.S. culture. He also stressed the "folk music" appeal to assert that the music could connect with world populations through an art form unique to the United States. ${ }^{93}$ In several respects, Gillespie's comments echoed several proponents of the Cultural Presentations program. Streibert, for example, told the

${ }^{89}$ Hearings before the Committee, 483.

${ }^{90}$ Hearings before the Committee, 484.

${ }^{91}$ For the full quotation, see Reinhold Wagnleitner, Coca-Colonization and the Cold War: The Cultural Mission of the United States in Austria after the Second World War (Chapel Hill: University of North Carolina Press, 1994), 212.

92 “Dizzy Urges Ike to Back Jazz Tours: Jazz Diplomat," Pittsburgh Courier, 4 August 1956, 15. This telegram was widely reported in newspapers and jazz trade publications, likely because someone associated with Granz or Gillespie issued it as a press release. African American newspapers, like the Pittsburgh Courier and New York Amsterdam News (among others), covered Gillespie's tours with enthusiasm and pride. See "Indians Dizzy over Gillespie's Jazz: Part 1"; "1,000 Jam Karachi Theatre for Dizzy," New York Amsterdam News, 21 April 1956, 16.

${ }^{93}$ In 1957 after further controversy erupted over his salary on the tours, Gillespie co-authored an Esquire article that elaborated on this point. He calls out Senator Ellender in particular. Dizzy Gillespie 
House committee that jazz is a "great resource of this country" and, in a written statement to the same committee, Representative Frank Thompson depicted jazz as a "cultural weapon" for which the United States "has a copyright." 94

Like Gillespie and others, Marshall Stearns also advocated for jazz's place in the Cultural Presentations program through various channels of print media, including his liner notes to World Statesman and Dizzy in Greece. ${ }^{95}$ As archival documents attest, Stearns presumably drafted these liner notes in conjunction with one another sometime between July and early September 1956 while debates raged over the State Department's use of jazz overseas. Several documents outline Stearns's overall strategy toward both LPs. World Statesman, as one handwritten note states, should take a "more general approach on Gillespie's effectiveness abroad." The same document also includes a track listing for Dizzy in Greece that includes seven pieces, all of which appear on the final LP. ${ }^{96}$ Significantly, the three tracks recorded at a later session in April 1957_- "That's All," "Stablemates," and "Groovin' High"—are not mentioned here or on Stearns's typed draft of the Dizzy in Greece liner notes. The published version of the notes is identical to Stearns's draft with one exception: a parenthetical phrase was added to account for the three tracks not mentioned in the draft. ${ }^{97}$ The 1956 date of these notes is further confirmed by a header in a separate document:

"Dizzy in Greece" 12 inch

Liner for Granz

Due Sept 7 airmail $^{98}$

Although no year is stated, the airmail due date likely refers to September 1956. Stearns's notes never mention material from the later session in April 1957 yet always accurately describe the other tracks in detail. Moreover, plans that outline

and Ralph Ginzburg, "Jazz Is Too Good for Americans," Esquire, June 1957, 140-43. Ingrid Monson analyzes the April 1957 controversy over Gillespie's pay in Monson, Freedom Sounds, 120-23, 355n38.

${ }^{94}$ Hearings before the Subcommittees of the Committee on Appropriations, House of Representatives, 736, 747. For one view on jazz as an "American icon," see Scott Gac, "Jazz Strategy: Dizzy, Foreign Policy, and Government in 1956," Americana: The Journal of American Popular Culture 4, no. 1 (Spring 2005). Non-U.S. musicians, of course, have been playing jazz throughout the music's history: S. Frederick Starr, Red and Hot: The Fate of Jazz in the Soviet Union, 1917-1980 (New York: Oxford University Press, 1983); Andrew F. Jones, Yellow Music: Media Culture and Colonial Modernity in the Chinese Jazz Age (Durham, NC: Duke University Press, 2001); Taylor Atkins, Blue Nippon: Authenticating Jazz in Japan (Durham, NC: Duke University Press, 2001); Michael H. Kater, Different Drummers: Jazz in the Culture of Nazi Germany (New York: Oxford University Press, 1992); Michael Dregni, Gypsy Jazz: In Search of Django Reinhardt and the Soul of Gypsy Swing (New York: Oxford University Press, 2008); Jeffrey H. Jackson, Making Jazz French: Music and Modern Life in Interwar Paris (Durham, NC: Duke University Press, 2003).

${ }^{95}$ Fosler-Lussier makes a similar argument about Stearns's use of print media, although she does not specifically mention these liner notes. Fosler-Lussier, Music in America's Cold War Diplomacy, $85-86$.

96 "Liner 1: Dizzy Gillespie World Statesman," handwritten document, b20 f1, MSC.

97 "Tunes (2)," handwritten document, b20 f1, MSC. For a detailed discography of the sessions, see the accompanying notes to Dizzy Gillespie, Birks Works: The Verve Big-Band Sessions, Verve Records ß314 527 900-2 1995, CD.

98 "Dizzy in Greece 12 inch," handwritten document, b20 f1, MSC. 
the structure and contents of each LP often appear in the same document and seem to have been drafted at the same time. ${ }^{99}$

Stearns conceived of both sets of liner notes as doing the same type of political work. A skeleton draft of the Dizzy in Greece liner notes makes it clear that Stearns wanted to foreground anecdotes from the band's tours in order to present Gillespie's travels as a triumph. Consider this brief outline:

1. range and overall success

2. Dacca一an example

3. Thru it all ... Diz as diplomat: mixed band, Ankara, snake charmer

4. why they loved it—generous etc.

5. " - real art

6. "-freedom ${ }^{100}$

By connecting the words "generous" and "freedom" to audience reception, Stearns aimed show how jazz cultivated political goodwill for the United States, a common theme in both liner notes. In total, Stearns appears to be answering a question posed in a handwritten note found in the margin of one of these drafts: "Topic: Is jazz good propaganda?"101

Not by coincidence, this question was also the title of an article Stearns published in the Saturday Review on 14 July $1956 .{ }^{102}$ Circulating two months after Gillespie's ensemble completed the first tour and before the release of World Statesman, the article argues for jazz's validity as a diplomatic tool. The music, Stearns writes, could "communicate more of the sincerity, joy, and vigor of the American way of life than several other American creations inspired by Europe." 103 Elsewhere in the article, he accentuates jazz's relationship to the "American way of life." "On the surface," he declares, "everybody—even the old folks—seemed to want to love jazz, even before they heard it. They definitely associated jazz with the cheerful, informal, and generous side of American life and they were bowled over by its spontaneity and vitality." 104

The article, both in tone and content, was the basis for Stearns's liner notes to World Statesman and Dizzy in Greece. Both liner notes link Gillespie's onstage performance to current events in order to argue for jazz's political relevance and

\footnotetext{
99 "Dizzy Gillespie: World Statesman—Volume 1," and "Dizzy in Greece—Volume II," typed drafts, b20 f1, MSC.

${ }^{100}$ Handwritten outline of Dizzy in Greece, b20 f1, MSC. The anecdotes from Dacca and Ankara were featured in the final version of the liner notes.

101 "Dizzy in Greece-Volume II," typed draft with handwritten annotations, b20 f1, MSC. Such rhetoric linking jazz to the notions of freedom and democracy was a significant part of legitimating the music. See Saul, Freedom Is, Freedom Ain't, 15; Iain Anderson, This Is Our Music: Free Jazz, the Sixties, and American Culture (Philadelphia: University of Pennsylvania Press, 2007), 38-43. For an overview of this practice in relation to the activities of the State Department, see Fosler-Lussier, Music in America's Cold War Diplomacy, 84-86.

${ }^{102}$ Marshall Stearns, "Is Jazz Good Propaganda? The Dizzy Gillespie Tour," Saturday Review, 14 July 1956.

${ }^{103}$ Stearns, "Is Jazz Good Propaganda?," 31.

${ }^{104}$ Stearns, "Is Jazz Good Propaganda?," 28.
} 
convince listeners that jazz's value extends beyond U.S. borders because of the music's ability to overcome cultural difference. ${ }^{105}$ In the notes to World Statesman, for example, he asserted that the band's "team-spirit" actively "spells out a new kind of freedom. Maybe that is why jazz is America's best-loved cultural export." 106 By metaphorically referring to the movement of goods across national boundaries, Stearns links jazz to the entrepreneurial spirit at the center of U.S. capitalism while his emphasis on the music's "vitality" associates the music with democratic ideals of progress, action, and freedom. ${ }^{107}$

Several stories appearing in both the liner notes and the Saturday Review article attempt to demonstrate the "generous side of American Life," a reoccurring phrase meant to explain how Gillespie's music reached local populations. ${ }^{108}$ Saxophonist Jimmy Powell, for example, donated reeds to a local musician, and Gillespie apparently quoted phrases from "Ochi Chornia," a famous Russian folk song, as a nod towards the Russian Folk Ballet members in attendance at one performance. ${ }^{109}$ Other stories directly addressed the tour's cultural politics. In one memorable anecdote, Gillespie invited a snake charmer into his room despite vigorous objections by hotel management; another describes Gillespie's refusal to play a concert in Ankara, Turkey, until the street children standing outside the gates were allowed to attend. Both World Statesman and Stearns's article quote Gillespie's explanation: "I came here to play for all the people." ${ }^{110}$ Altogether, Stearns establishes that Gillespie's version of diplomacy meant sharing his music with everyone, regardless of social, economic, or ethnic position. Jazz, in this view, unifies people through its capacity to engage peacefully across difference while also respecting individual forms of expression.

The idea of jazz's moral imperative can also be seen in Stearns's first monograph, The Story of Jazz, published in 1956, around the same time as World Statesman. ${ }^{111}$ The book portrays jazz as a uniquely "American" contribution to the world. "Jazz,"

${ }^{105}$ For an earlier example of liner notes explicitly relating jazz to Cold War politics, see Louis Armstrong, Ambassador Satch, Columbia CL 840, 1956, LP (12in).

${ }^{106}$ Stearns, liner notes to World Statesman. Characterizations of jazz as a cultural export were common in the mid-1950s. Time magazine, for example, called jazz a "valuable exportable U.S. commodity." "Music: Jazz around the World," Time, 25 June 1956.

${ }^{107}$ The appropriations request of the "President's Special International Program" for the fiscal year 1957 included funding for both the Cultural Presentations programs and the international tradefair participation run through the Department of Commerce and promoted through the USIA. It is doubtful that Stearns was referring to this bureaucratic link, but it nevertheless demonstrates how the Cultural Presentations programs were only part of a diverse diplomatic strategy. See the budget proposal reproduced in Hearings before the Committee on Appropriations, United States Senate, 441-70.

${ }^{108}$ The phrase appears verbatim in both liner notes.

${ }^{109}$ In his Saturday Review article, Stearns devotes several paragraphs to the exchange between the Russian dancers and Gillespie's ensemble, although it remains unclear about the specific Russian ensemble that was in attendance. He writes: "Backstage, members of the Russian Folk Dance troupe, which alternated with U.S. at the same theatre, were jitterbugging quietly, deadpan." Stearns, "Is Jazz Good Propaganda?," 30-31.

110 Stearns, liner notes to World Statesman and Dizzy in Greece; Stearns, "Is Jazz Good Propaganda?," 30-31.

${ }^{111}$ Marshall Stearns, The Story of Jazz (New York: Oxford University Press, 1956). In his review, Hentoff praised the book for its "sociological" insights. Nat Hentoff, "Marshall Stearns Writes Best-Yet History of Jazz," Down Beat, 28 November 1956, 17. 
he writes in the introduction, "has played a part, for better or worse, in forming the American character." 112 One of the later chapters focuses on Gillespie's State Department tours and describes the music as a "secret sonic weapon" in the war against communism. ${ }^{113}$ In "win[ning] over the people," he writes, "the friendly and free wheeling band ... led many people to abandon their communist-inspired notions of American democracy in the course of one concert." 114

Stearns's presentation of Gillespie as a symbol of national pride and racial harmony also fit within Granz's worldview of jazz and its potential to enact social change. Beginning in the 1940s, Granz included an anti-discrimination clause in his contracts that guaranteed desegregated audiences, even while traveling in the South. ${ }^{115}$ When he first presented the jam-session style concerts under the Jazz at the Philharmonic banner in 1944, he did so as a benefit for twenty-one Mexican youths convicted of crimes committed during the Zoot Suit Riots of 1943. That same year, he organized concerts to support the Fair Employment Practices Commission and other organizations fighting for anti-lynching legislation. ${ }^{116}$ His business acumen provided a steady stream of concerts, recordings, and promotional opportunities for his musicians. Yet even as one of the jazz industry's most successful entrepreneurs, he always conducted his business with a politically conscious edge. ${ }^{117}$

When Norgran issued World Statesman at the end of 1956, Granz no doubt considered it smart business practice to take advantage of Gillespie's national exposure as an active agent on the Cold War's front line then circulating through the various print media. He also recognized how his primary business, selling records, could interact with the culture of print-capitalism that, as Benedict Anderson famously argues, is vital to constructing the nation-state. ${ }^{118}$ With these recordings, Granz seemingly took advantage of the moment in order to present Gillespie to a broad audience and place jazz on a national stage where discourses of racial discrimination and unequal citizenship were in continuous circulation.

\section{Conclusion: Dizzy the Diplomat}

During an onstage moment in an unidentified South American city, Gillespie unexpectedly catches himself playing the straight man. "And now ladies and gentleman," he begins a bit stiffly before pausing and commenting to himself, "Oh, I'm out of

112 Stearns, The Story of Jazz, xi.

113 The concept of jazz as a "secret sonic weapon" originates from a front-page article in the New York Times: Felix Belair, "United States Has Secret Sonic Weapon-Jazz,” New York Times, 6 November $1955,1,42$.

${ }^{114}$ Stearns, The Story of Jazz, 294-95.

115 Granz biographer Tad Hershorn details how Granz actively encouraged other bandleadersincluding Jimmy Dorsey, Duke Ellington, Stan Kenton, and Benny Goodman, among others-to similarly place anti-discrimination language in their contracts. Hershorn, Norman Granz, 105.

116 Monson, Freedom Sounds, 37.

${ }^{117}$ Hershorn refers to such actions in his subtitle, The Man Who Used Jazz for Justice. Although some musicians spoke out against Granz's preferred concert format, they generally praised him for his equitable business practices. Hershorn, Norman Granz, 195.

${ }^{118}$ Benedict Anderson, Imagined Communities: Reflections on the Origin and Spread of Nationalism, 2nd ed. (New York: Verso, 1991), 42-46. 
character." 119 This admission, however brief, testifies to his awareness of what it meant to be "in character" while on stage. Whether during a spoken introduction or while improvising during within a tune, Gillespie's performance was not simply about music making, but was also a way to transmit cultural knowledge, memory, and citizenship through embodied action. ${ }^{120}$ Indeed, his creativity on and off the bandstand helped him negotiate the shifting political landscape of jazz during a crucial time of upheaval on a worldwide stage.

As Gillespie and others clearly realized, the use of jazz as a weapon against Soviet propaganda through unprecedented support from the U.S. government presented an opportunity to raise the music's profile and cultural positioning. Gillespie's LPs, as one small piece of the puzzle, invariably engaged with domestic debates about civil rights within the United States. As a result, the LPs' content became less about what actually took place on the tours and more about making the music legible to U.S. audiences not already invested in jazz for its own sake. Here, the omission of any reference to the South American tour looms large. By only including Gillespie's activities in Eastern Europe and the Middle East, the LPs purposefully appealed to the stature that Europe still maintained with U.S. audiences. The records explicitly portrayed themselves as a jazz "concert" without Gillespie's vocal commentary or characteristic humor. This marketing strategy toward a political end can also be seen on the cover of Dizzy in Greece, with Gillespie in his white fustanella, leaning against the pillars of a temple that had resiliently stood the test of time. By implication, the music should as well.

The discrepancies in repertoire between the LPs and tour concerts speak to the different kinds of political work each was attempting to accomplish. The tours' success depended on collaboration between an interracial group of musicians and the nation-state that, on stage, performed a positive version of U.S. culture for local populations. Gillespie used this opportunity to stage an inherently hybrid and diverse vision for the United Sates, one that foregrounded African American expressive culture. The LPs told a related but different story about jazz and its political effectiveness in the world. The jazz tours were a start, but it was equally important for U.S. audiences to understand jazz as a participant in the serious business of diplomacy. The LPs rendered jazz as "American" music through their audiovisual design, depicting Gillespie as a dignitary fit for the resolute work of an ambassador.

Reading this political moment through the overlapping structures and networks of the music business points to how the circulation of performance on record attempted to shape the discourse surrounding jazz and musical diplomacy. The industry's adoption of the 12-inch LP and the resultant increase of sales across a wide spectrum of consumers made the musical format into a media of mainstream popular culture during the mid-1950s. These changes greatly influenced Granz as he positioned Verve within the already well-established channels of print-capitalism, especially those publications aimed at middle-class white audiences. Recordings

${ }^{119}$ This comment can be heard on "Stella by Starlight" (0:02), from Gillespie, Official U.S. State Department Tour, 1956: Volume 1.

${ }^{120}$ For more on this view of performance, see Taylor, Archive and the Repertoire, xvi, 2-3, 20-21. 
such as Gillespie's became visual, aural, and physical representations of the political moment, moving jazz into a contested arena of mid-century U.S. culture. World Statesman and Dizzy in Greece, as two 12-inch black vinyl records, were objects through which the abstract connection between jazz and the nation-state materialize. ${ }^{121}$

Both LPs adopted the same language and rhetorical strategies as other forms of print media covering Gillespie's ambassadorial tours. These records attempted to make Gillespie's music audible to the various strata of U.S. culture by convincing listeners of jazz's import and relevance. Recall the first words of Dizzy in Greece:

\begin{abstract}
This is the second album (the first was DIZZY GILLESPIE: WORLD STATESMAN) of the music that piled up friends and momentum as it swung through the Middle East on the first State Department tour in jazz history. Once more, the power of jazz as a world-wide force for goodwill was documented to the hilt and, shortly thereafter, jazz band tours became a fixed part of government policy. ${ }^{122}$
\end{abstract}

Using Gillespie's activities as evidence, the LPs stress the historical significance of jazz's use in an official capacity by the State Department for the first of many times to come. Because the tours ultimately survived the public debates about the merits of jazz diplomacy, as well as a forceful pushback from Congress, the notes at once celebrate Gillespie as a trailblazer and as a political victor. In this way, both LPs were not objects of the past, but media that imagined jazz's future.

\title{
References
}

\section{Archives}

Dizzy Gillespie Newspaper Clippings. Institute of Jazz Studies. Rutgers University Libraries.

The Marshall Winslow Stearns Collection (MC 030). Institute of Jazz Studies. Rutgers University Libraries.

The Newport Jazz Festival Records (MC 038). Institute of Jazz Studies. Rutgers University Libraries.

\section{Books and Articles}

“1,000 Jam Karachi Theatre for Dizzy.” New York Amsterdam News, 21 April 1956, 16.

“1957 Deejay Poll.” Down Beat, 30 May 1957, 12.

Anderson, Benedict. Imagined Communities: Reflections on the Origin and Spread of Nationalism. 2nd ed. New York: Verso, 1991.

${ }^{121}$ My reading of the LP as an object of cultural materialization within the contexts of a rising global market and mass consumerism in the U.S. is also influenced by David Kazanjian's discussion of power structures formed through the production, distribution, and consumption of goods. David Kazanjian, The Colonizing Trick: National Culture and Imperial Citizenship in Early America (Minneapolis: University of Minnesota Press, 2003), 27.

122 Stearns, liner notes to Dizzy in Greece. 
Anderson, Iain. This Is Our Music: Free Jazz, the Sixties, and American Culture. Philadelphia: University of Pennsylvania Press, 2007.

Atkins, Taylor. Blue Nippon: Authenticating Jazz in Japan. Durham, NC: Duke University Press, 2001.

Belair, Felix. "United States Has Secret Sonic Weapon-Jazz." New York Times, 6 November 1955, 1, 42.

Berliner, Paul. Thinking in Jazz: The Infinite Art of Improvisation. Chicago: University of Chicago Press, 1994.

"Best Sellers." Down Beat, 6 March 1957, 32.

"Best Sellers." Down Beat, 4 April 1957, 21.

"Best Sellers." Down Beat, 30 May 1957, 22.

"Best Sellers." Down Beat, 27 June 1957, 24.

Carletta, David. “Those White Guys Are Working for Me: Dizzy Gillespie, Jazz, and the Cultural Politics of the Cold War during the Eisenhower Administration." International Social Science Review 82, nos. 3-4 (2007): 115-34.

Carpio, Glenda. Laughing Fit to Kill: Black Humor in the Fictions of Slavery. New York: Oxford University Press, 2008.

Cuscuna, Michael, and Michel Ruppli. The Blue Note Label: A Discography. Westport, CT: Greenwood Press, 2001.

Davenport, Lisa E. Jazz Diplomacy: Promoting America in the Cold War Era. Jackson: University Press of Mississippi, 2009.

DeVeaux, Scott. The Birth of Bebop: A Social and Musical History. Berkeley: University of California Press, 1997.

“Dizzy Gillespie, Nat Cole Entertain President.” Jet Magazine, 7 June 1956.

“Dizzy Urges Ike to Back Jazz Tours: Jazz Diplomat.” Pittsburgh Courier, 4 August 1956, 15.

"Dizzy Winds up 'Person-Person' Show Friday." The Washington Afro-American, 26 June 1956, 17.

Dregni, Michael. Gypsy Jazz: In Search of Django Reinhardt and the Soul of Gypsy Swing. New York: Oxford University Press, 2008.

Dudziak, Mary L. Cold War Civil Rights: Race and the Image of American Democracy. Princeton, NJ: Princeton University Press, 2000.

"Ella: It Took a Hit Album to Make Miss F. A Class Nitery Attraction.” Down Beat, 28 November 1956, 13.

Feather, Leonard. “This Melba Is a Peach.” Down Beat, 16 September 1956, 16.

Feld, Steven. Jazz Cosmopolitanism in Accra: Five Musical Years in Ghana. Durham, NC: Duke University Press, 2012.

"Fitzgerald to Granz Label." Down Beat, 8 February 1956, 8.

Fosler-Lussier, Danielle. Music in America's Cold War Diplomacy. Oakland: University of California Press, 2015.

Franzius, Andrea Georgia Marina. "Soul Call: Music, Race, and the Creation of American Cultural Policy.” Ph.D. diss., Duke University, 2006.

Gac, Scott. “Jazz Strategy: Dizzy, Foreign Policy, and Government in 1956.” Americana: The Journal of American Popular Culture 4, no. 1 (Spring 2005).

Gennari, John. Blowin' Hot and Cool: Jazz and Its Critics. Chicago: University of Chicago Press, 2006. 
Gillespie, Dizzy, and Al Fraser. To Be, or Not ... To Bop. Garden City, NY: Doubleday, 1979.

Gillespie, Dizzy, and Ralph Ginzburg. "Jazz Is Too Good for Americans.” Esquire, June 1957, 55, 140-43.

Gold, Don. "Dizzy Gillespie: Dizzy in Greece (Review).” Down Beat, 28 November $1957,28-29$.

"Granz Forms Two Labels, Dickers for Mars Masters, Cuts EP Price." Down Beat, 8 February 1956, 8.

“Granz Unifies Four Disceries under Verve Banner.” Down Beat, 20 February 1957, 10.

Hentoff, Nat. "Dizzy Gillespie Orchestra: Birdland, New York.” Down Beat, 11 July 1956, 18.

_. "Marshall Stearns Writes Best-Yet History of Jazz." Down Beat, 28 November 1956, 17.

_. "World Statesman (Review)." Down Beat, 26 December 1956, 30.

Hershorn, Tad. Norman Granz: The Man Who Used Jazz for Justice. Berkeley: University of California Press, 2011.

"History of Jazz Big Feature of Gillespie Overseas Tour." Down Beat, 2 May 1956, 9.

"Indians Dizzy over Gillespie’s Jazz: Part 1." Pittsburgh Courier, 2 June 1956, 22.

Iton, Richard. In Search of the Black Fantastic: Politics and Popular Culture in the Post-Civil Rights Era. New York: Oxford University Press, 2008.

Jackson, Jeffrey H. Making Jazz French: Music and Modern Life in Interwar Paris. Durham, NC: Duke University Press, 2003.

Jones, Andrew F. Yellow Music: Media Culture and Colonial Modernity in the Chinese Jazz Age. Durham, NC: Duke University Press, 2001.

Kater, Michael H. Different Drummers: Jazz in the Culture of Nazi Germany. New York: Oxford University Press, 1992.

Kazanjian, David. The Colonizing Trick: National Culture and Imperial Citizenship in Early America. Minneapolis: University of Minnesota Press, 2003.

Kelley, Robin D. G. Africa Speaks, America Answers: Modern Jazz in Revolutionary Times. Cambridge, MA: Harvard University Press, 2012.

Maggin, Donald L. Dizzy: The Life and Times of John Birks Gillespie. New York: Harper Entertainment, 2005.

Martin, Waldo E. No Coward Soldiers: Black Cultural Politics and Postwar America. Cambridge, MA: Harvard University Press, 2005.

Monson, Ingrid T. Freedom Sounds: Civil Rights Call out to Jazz and Africa. New York: Oxford University Press, 2007.

Moreno, Jairo. "Bauza-Gillespie-Latin/Jazz: Difference, Modernity, and the Black Caribbean." South Atlantic Quarterly 103, no. 1 (2004): 81-99.

Morton, David. Sound Recording: The Life Story of a Technology. Westport, CT: Greenwood Press, 2004.

Mueller, Darren. "At the Vanguard of Vinyl: A Cultural History of the Long-Playing Record in Jazz." Ph.D. diss., Duke University, 2015.

"Music Jazz around the World." Time, 25 June 1956.

O’Malley, Brendan and Ian Craig. The Cyprus Conspiracy: America, Espionage, and the Turkish Invasion. New York: I. B. Tauris, 1999. 
Priestley, Brian. Liner Notes to the Jazz Scene. Verve 314521 661-2, 1994, CD.

Radano, Ronald M. Lying up a Nation: Race and Black Music. Chicago: University of Chicago Press, 2003.

"Rioters in Athens Stone U.S. Office." New York Times, 10 May 1956, 1.

Saul, Scott. Freedom Is, Freedom Ain't: Jazz and the Making of the Sixties. Cambridge, MA: Harvard University Press, 2003.

Shelton, Robert. "Happy Tunes on Cash Registers.” New York Times, 16 March 1958, XX14.

Shipton, Alyn. Groovin' High: The Life of Dizzy Gillespie. New York: Oxford University Press, 1999.

"Standalone Photo." New York Amsterdam News, 7 April 1956, 16.

Starr, S. Frederick. Red and Hot: The Fate of Jazz in the Soviet Union, 1917-1980. New York: Oxford University Press, 1983.

Stearns, Marshall. “Dizzy's Troupe Casts Spell over Mideast Audiences.” Down Beat, 17 June 1956, 16.

—. "Is Jazz Good Propaganda? The Dizzy Gillespie Tour." Saturday Review, 14 July 1956, 28-31.

—. "Turkey Resounds, Reacts to Dizzy Gillespie Band.” Down Beat, 27 June 1956, 16.

- Liner Notes to Dizzy in Greece. Verve MV-2630, 1957, LP.

- Liner Notes to World Statesman. Norgran Records MG N-1084, 1956, LP. The Story of Jazz. New York: Oxford University Press, 1956.

The Supplemental Appropriation Bill, 1957: Hearings before Subcommittees of the Committee on Appropriations, House of Representatives, Eighty-Fourth Congress, Second Session, Part 2. Washington D.C.: United States Government Printing Office, 1956.

The Supplemental Appropriation Bill, 1957: Hearings before the Committee on Appropriations, United States Senate, Eighty-Fourth Congress, Second Session, on H.R. 12138, an Act Making Supplemental Appropriations for the Fiscal Year Ending June 30, 1957, and for Other Purposes. Washington, D.C.: U.S. Government Printing Office, 1956.

Taylor, Diana. The Archive and the Repertoire: Performing Cultural Memory in the Americas. Durham, NC: Duke University Press, 2003.

Von Eschen, Penny. Race against Empire: Black Americans and Anticolonialism, 1937-1957. Ithaca, NY: Cornell University Press, 1997.

- Satchmo Blows up the World: Jazz Ambassadors Play the Cold War. Cambridge, MA: Harvard University Press, 2004.

Wagnleitner, Reinhold. Coca-Colonization and the Cold War: The Cultural Mission of the United States in Austria after the Second World War. Chapel Hill: University of North Carolina Press, 1994.

\section{Recordings}

Armstrong, Louis. Ambassador Satch. Columbia CL 840, 1956, LP (12in).

Gillespie, Dizzy. Birks' Works. Verve MG V-8222, 1957, LP (12in). 
. Birks Works: The Verve Big-Band Sessions. Verve Records 314527 900-2, 1995, CD.

- World Statesman. Norgran Records MG N-1084, 1956, LP (12in).

-. Dizzy Gillespie at Newport. Verve MG VS-6023, 1957, LP (12in).

. Dizzy in Greece. Verve MV-2630, 1957, LP (12in).

- Dizzy in South America Official U.S. State Department Tour, 1956:

Volume 1. Consolidated Artists Production CAP 933, 1999, CD.

- Dizzy in South America Official U.S. State Department Tour, 1956:

Volume 2. Consolidated Artists Production CAP 934, 1999, CD.

. Dizzy in South America: Volume 3. Consolidated Artists Productions CAP 935, 2001, CD.

Gillespie, Dizzy, and Roy Eldridge. Trumpet Battle. Clef 730, 1954, LP (12in).

Jazz at the Philharmonic: Presented by Norman Granz. Stinson Records S453, 1945, 78 (12in).

The Jazz Scene. Mercury 2071, 1950, 78 (12in).

\section{Interview}

Dave Usher, telephone interview with author, 9 July 2015. 